\title{
Pollination Efficiency of Apis mellifera L. (Hymenoptera: Apidae) on Flowers of Sesamum indicum L. (Pedaliaceae) at Bilone (Obala, Cameroon)
}

\author{
Pharaon Mbianda Auguste ${ }^{1 *}$, Dounia ${ }^{2}$, Chantal Douka ${ }^{2}$, Esther Nadine Otiobo Atibita ${ }^{3}$, \\ Fernand-Nestor Tchuenguem Fohouo ${ }^{1}$ \\ ${ }^{I}$ Laboratory of Applied Zoology, Faculty of Sciences, University of Ngaoundéré, Cameroon \\ ${ }^{2}$ Laboratory of Zoology, Higher Teacher Training College, University of Yaoundé I, Cameroon \\ ${ }^{3}$ Department of Biological Sciences, Faculty of Science, University of Bamenda, Cameroon
}

*Corresponding Author: Pharaon Mbianda Auguste, Laboratory of Applied Zoology, Faculty of Sciences, University of Ngaoundéré, Cameroon

\begin{abstract}
To evaluate Apis mellifera impact on pod and seed yields of Sesamum indicum, its foraging and pollinating activities were studied in Bilone during the rainy season of 2016 and 2017. Treatments included unlimited floral access by all visitors, bagged flowers to avoid all insects' pollinators and limited of single visit of A. mellifera worker. For each year of study, observations were made on $40 \pm 7$ flowers per treatment. Apis mellifera foraging behavior and its pollination efficiency were evaluated. Results show that this bee foraged nectar and pollen on S. indicum flowers during the whole blooming period. The number of seeds per pod and the percentage of normal seeds of unprotected flowers were significantly higher than those of flowers protected from insects $(P<0.001)$. Through its pollination efficiency, A. mellifera provoked a significant increment of the number of seeds per pod by $17.54 \%$ in 2016 and $8.77 \%$ in 2017, and the percentage of normal seeds by $9.53 \%$ in 2016 and $7.70 \%$ in 2017. The installation of A. mellifera colonies close to S. indicum fields is recommended to increase pod and seed yield in the region.
\end{abstract}

Keywords: Apis mellifera, Sesamum indicum, flower, pollination.

\section{INTRODUCTION}

Several plant species depend on insect pollinators for their reproduction [1, 2]. In agro ecosystems, these pollinators have a great ecological and economic importance because they influence positively plant productions [2, 3]. Sesamum indicum is annual plant originated from Africa [4]. Sesame plants grow upright to $3 \mathrm{~m}$ and carry many flowers per branch; these flowers are white, but can vary from pink to red and produce nectar and pollen that attract insects $[5,6]$. China and Indian are the largest producers of sesame in the world [7]. The fruit is a pod containing four raw of twelve seeds [8]. Seeds contain oil (63\%), proteins (31\%), glucose (3\%) and minerals that are important for human's diets [9]. The research conducted in India by Viraktmath et al. [10], in Egypt by Kamel et al. [11] and in Northwest Region of Cameroon by Atibita et al. [12] have revealed that Apis mellifera visits $S$. indicum flowers and collect nectar and pollen. No previous research has been reported on the relationships between S. indicum flowers and A. mellifera in Bilone (Center Region, Cameroon), although, the activities of insects on the flowers can vary with regions [3, 13]. The main objective of this research was to gather more data on the relationships between S. indicum and A. mellifera. Specific objectives were to study the activities of this bee on $S$. indicum flowers and to evaluate its pollination efficiency on pod and seed yields.

\section{MATERIALS AND METHODS}

\subsection{Site and biological materials}

The studies were conducted twice, March to June in 2016 and 2017 in a field located at the campus of the Institute of Agronomy at Bilone (Obala) (Latitude: N 04.20514², Longitude: E $011.51694^{\circ}$, Altitude: $525 \mathrm{~m}$ ) in the Center Region of Cameroon. This Region belongs to the tropical rainforest 
Pollination Efficiency of Apis mellifera L. (Hymenoptera: Apidae) on Flowers of Sesamum indicum L. (Pedaliaceae) at Bilone (Obala, Cameroon)

agro-ecological zone [14]. The climate is equatorial guinean-type with four seasons: the peak rainy season (August to November), the peak dry season (November-March), the mild rainy season (MarchJuly) and the mild dry season (July-August), the mean annual temperature is $25^{\circ} \mathrm{C}$, while the mean annual relative humidity is $79 \%$ [15]. The experimental plot was an area of $800 \mathrm{~m} 2$. The animal material was represented by insects naturally present in the environment and a colony of A. mellifera (Hymenoptera: Apidae) located $22 \mathrm{~m}$ from the experimental field. Vegetation was represented by wild species and cultivated plants. The plant material was represented by the seeds of $S$. indicum provided by the Institute of Agricultural Research for Development in Nkolbisson (Yaoundé).

\subsection{Planting and maintenance of culture}

On March 15, 2016 and 2017, the experimental plot was divided into six subplots ( $6 * 5.5 \mathrm{~m} 2)$. Seeds were sown on five lines per subplot; each line had five holes and each hole received 10 to 14 seeds. The spacing was $1 \mathrm{~m}$ between rows and $1 \mathrm{~m}$ on rows. Each hole was $4 \mathrm{~cm}$ depth. Two weeks after germination, the plants were thinned and only two were left per hole. Weeding was performed manually as necessary to maintain plot weeds-free.

\subsection{Determining the reproduction mode}

In May 18 and May 23respectively in 2016 and 2017, 90 flowers of S. indicum at the bud stage were labeled. Fourty five of the total number flowers were allowed for treatment 1 (open pollination) and 45 others flowers belong to treatment 2 (bagged with gauze bags to prevent visitors or external pollinating agents) (figure 1). For each year, fifty days after the wilting of the last flower, the number of pod formed in each treatment was counted. For each treatment, the fruiting index (Ifr) was then calculated using the following formula: $I f r=(F 1 / F 2)$, where $F 1$ is the number of pod formed and $F 2$ the number of flowers initially labeled [16]. The out crossing rate $(T C)$ was calculated using the formula: $T C=\left\{\left[\left(I f r_{X}-I f r_{Y} / I f r_{X}\right] * 100\right\}\right.$, where $I f r_{X}$ and $I f r_{Y}$ are mean fruiting indexes in treatments 1 and 2 respectively [17]. The rate of self-pollination in the broad sense $(T A)$ was calculated using the formula: $T A=(100-T C)$.

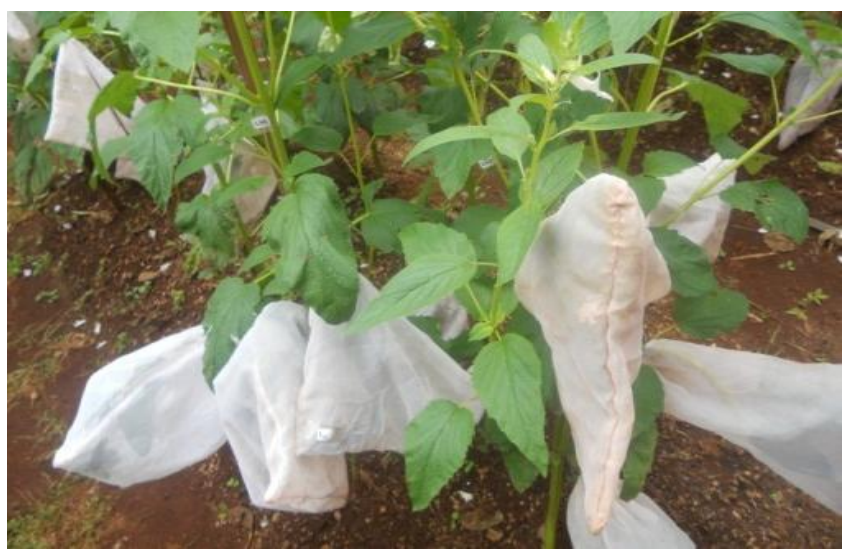

Figure1. Plants of Sesamum indicum showing flowers isolated from insects

\subsection{Study of the activity of Apis mellifera on Sesamum indicum flowers}

Observations were conducted on individually opened flowers of treatment 1 each day, from May 26 to June 12 in 2016 and from May 21 to June 18 in 2017 at one hour interval from 9 to $16 \mathrm{~h}(9-10 \mathrm{~h}, 11$ $12 \mathrm{~h}, 13-14 \mathrm{~h}, 15-16 \mathrm{~h}$ ). In a slow walk along all labeled flowers of treatment 1 , the identity of all insects that visited $S$. indicum flowers was recorded. All insects encountered on flowers were recorded and the cumulated results expressed in number of visits to determine the relative frequency of $A$. mellifera in the anthophilous entomofauna of $S$. indicum. Direct observations of the foraging activity of worker bees on flowers were made. The floral products (nectar and/or pollen) collected by the foragers were recorded for the same dates and time slots as that of the insect counts. The duration of visits and the foraging speed (number of flowers visited per minute) [16] were timed to the same dates and in four time slots $(10-11 \mathrm{~h}, 12-13 \mathrm{~h}, 14-15 \mathrm{~h}, 16-17 \mathrm{~h}$ ). Abundances (larger numbers of individuals simultaneously active) per flower and per 1000 flowers $\left(A_{1000}\right)$ were recorded on the same dates and time slots as that of the registration of the duration of visits. The first parameter was recorded as a result of direct counts. For the abundance per 1000 flowers, honeybees were counted on 
Pollination Efficiency of Apis mellifera L. (Hymenoptera: Apidae) on Flowers of Sesamum indicum L. (Pedaliaceae) at Bilone (Obala, Cameroon)

a known number of open flowers; $A_{1000}=[(A x / F x) * 1000]$, where $F_{x}$ and $A_{x}$ are respectively the number of flowers and the number of individual bees actually counted on $F_{x}$ [16]. During the days of investigation, the temperature and humidity of the study site were recorded every $30 \mathrm{~min}$, from 9 am to $17 \mathrm{pm}$, using a thermo hygrometer installed in the shade.

\subsection{Evaluation of the impact of pollinating insects on Sesamum indicum yield}

This evaluation was based on the impact of flowering insect on pollination, the impact of pollination on fruiting and the comparison of yields (fruiting rate, mean number of seeds per pod and percentage of normal i.e. well developed seeds) of treatment 1 (unprotected flowers) and treatment 2 (bagged flowers). The fruiting rate due to the influence of foraging insects $\left(F r_{i}\right)$ was calculated using the formula: $F r_{i}=\left\{\left[\left(F r_{X}-F r_{Y}\right) / F r_{X}\right] * 100\right\}$, where $F r_{X}$ and $F r_{Y}$ are the fruiting rate in treatments 1 and 2 respectively. The fruiting rate of a treatment $(F r)$ is $F r=\left[\left(F_{2} / F_{1}\right) * 100\right]$, where, $F_{2}$ is the number of pods formed and $F_{l}$ the number of viable flowers initially set [16]. At maturity, pods were harvested from all treatments. The mean number of seeds per pod and the percentage of normal seeds were then calculated for each treatment.

\subsection{Assessment of the pollination efficiency of Apis mellifera on Sesamum indicum}

In 2016, along with the development of treatment 1 and 2, 30 flowers were protected using gauze bag (treatment 3). In 2017 the same experience was repeated with the same number of flowers. Between 6 and $9 \mathrm{am}$, the gauze bag is gently removed from each newly bloomed flower which was then observed during for one to $20 \mathrm{~min}$. Flowers visited by A. mellifera were marked. After this manipulation, the flowers were protected once more. The impact of A. mellifera on fruiting rate $(P f x)$ was calculated using the following formula: $P f x=\{[(f 3-f 2) / f 3] * 100\}$, where $f 3$ and $f 2$ are the fruiting rates in treatment 3 (protected flowers visited exclusively by A. mellifera) and treatment 2 (protected flowers) [16]. The number of seeds per pod, the percentage of normal seeds was then calculated for each treatment 3 .

\section{Data analysis}

SPSS software and Microsoft Excel were used for three tests: Student's $(t)$ for the comparison of means, correlation coefficient $(r)$ for the study of linear relationship between two variables, Chisquare $(\chi 2)$ for the comparison of percentages.

\section{Results}

\subsection{Reproduction mode}

In 2016, the podding index was 0.77 for treatment 1 and 0.25 for treatment 2 , while in 2017, it was 0.73 and 0.62 for the two treatments respectively. Consequently, in 2016 the allogamy rate was 25.97 $\%$ and the autogamy rate was $74.03 \%$. In 2017, the corresponding figures were $15.06 \%$ and 84.94 $\%$. It appears that the variety of $S$. indicum used in our experiments has a mixed reproduction mode, autogamous -allogamous, with the predominance of autogamy over allogamy.

\subsection{Activity of Apis mellifera on Sesamum indicum flowers}

\subsubsection{Seasonal frequency of visits}

Amongst the 467 and 715 visits of 13 and 15 insects species recorded on S. indicum flowers respectively in 2016 and 2017, A. mellifera was the most represented insect with 194 visits $(41.54 \%)$ in 2016 and 327 visits (45.73\%) in 2017 (Table 1). The difference between these two percentages is not significant $\left(\chi^{2}=2.02 ; d f=1 ; P>0.05\right)$.

Table 1: Diversity of insects on Sesamum indicum flowers in 2016 and 2017, number and percentage of visits of different insects at Bilone

\begin{tabular}{|c|c|c|c|c|c|c|c|c|c|}
\hline \multicolumn{4}{|c|}{ Insects } & \multicolumn{2}{|c|}{2016} & \multicolumn{2}{|c|}{2017} & \multicolumn{2}{|c|}{ Total } \\
\hline Order & Family & Genus, $\quad$ species, Sub & - & $n_{1}$ & $p_{1} \%$ & $n_{2}$ & $p_{2} \%$ & $n_{1,2}$ & $p_{1,2} \%$ \\
\hline & Calliphoridae & $(1 \mathrm{sp} .)^{\mathrm{nt}}$ & & 8 & 1.71 & 0 & 0 & 8 & 0.68 \\
\hline Diptera & Muscidae & Musca domestica $^{\mathrm{nt}}$ & & 29 & 6.21 & 39 & 5.45 & 68 & 5.75 \\
\hline Hymenop & Apidae & Apis mellifera ${ }^{\mathrm{po}, \mathrm{nt}}$ & & 194 & 41.54 & 327 & 45.73 & 521 & 44.07 \\
\hline & & Xylocopa olivacea $^{\mathrm{po}, \mathrm{nt}}$ & & 37 & 7.92 & 58 & 8.11 & 95 & 8.04 \\
\hline
\end{tabular}


Pollination Efficiency of Apis mellifera L. (Hymenoptera: Apidae) on Flowers of Sesamum indicum L. (Pedaliaceae) at Bilone (Obala, Cameroon)

\begin{tabular}{|c|c|c|c|c|c|c|c|c|}
\hline & & Amegilla sp. ${ }^{\mathrm{po}, \mathrm{nt}}$ & 59 & 12.63 & 46 & 6.43 & 105 & 8.89 \\
\hline & Eumenidae & Delta $\mathrm{sp} .{ }^{\mathrm{nt}}$ & 0 & 0 & 12 & 1.67 & 12 & 1.02 \\
\hline & Formicidae & $(1 \mathrm{sp} .)^{\mathrm{nt}}$ & 6 & 1.28 & 53 & 7.41 & 59 & 4.99 \\
\hline & Halictidae & Lasioglossum sp. $^{\mathrm{po}, \mathrm{nt}}$ & 0 & 0 & 37 & 5.17 & 37 & 3.13 \\
\hline & Megachilidae & Chalicodoma sp. $^{\mathrm{nt}}$ & 81 & 17.34 & 38 & 5.31 & 119 & 10.07 \\
\hline & & Megachile sp. $^{\mathrm{po}, \mathrm{nt}}$ & 16 & 3.43 & 63 & 8.81 & 79 & 6.68 \\
\hline & Vespidae & Synagris cornuta ${ }^{\mathrm{po}, \mathrm{nt}}$ & 4 & 0.86 & 7 & 0.97 & 11 & 0.93 \\
\hline Lepidoptera & Acraeidae & Acraea acerata $^{\mathrm{nt}, \mathrm{rt}}$ & 9 & 1.93 & 6 & 0.83 & 15 & 1.27 \\
\hline & Pieridae & Catopsilia flerella ${ }^{\mathrm{nt}, \mathrm{rt}}$ & 5 & 1.07 & 3 & 0.41 & 8 & 0.68 \\
\hline & Nymphalidae & $(1 \mathrm{sp} .)^{\mathrm{nt}, \mathrm{rt}}$ & 0 & 0 & 7 & 0.97 & 7 & 0.59 \\
\hline Orthoptera & & $(1 \mathrm{sp} .)^{\mathrm{df}}$ & 7 & 1.50 & 15 & 2.09 & 22 & 1.86 \\
\hline Nevroptera & & $(1 \mathrm{sp} .)^{\mathrm{pr}}$ & 12 & 2.58 & 4 & 0.55 & 16 & 1.35 \\
\hline Total & \multicolumn{2}{|l|}{16 species } & 467 & 100 & 715 & 100 & 1182 & 100 \\
\hline
\end{tabular}

$n_{1}$ : number of visits on 45 flowers in 16 days. $n_{2:}$ number of visits on 45 flowers in 23 days. $p_{1}$ et $p_{2}$ : percentages of visits. $p_{1}=\left(n_{1} / 467\right) * 100 . p_{2}=\left(n_{2} / 715\right) * 100 . n_{l, 2}=\left(n_{l}+n_{2}\right) \cdot p_{1,2}=\left[\left(n_{1}+n_{2}\right) / 1182\right] * 100$. nt : visitor collected nectar. po: visitor collected pollen. df: defoliator. rt: rest. pr: predator. sp.: undetermined species.

\subsubsection{Floral substances harvested}

From our field observations, A. mellifera workers were found to collect pollen and to harvest nectar on S. indicum flowers (Figure 2). In 44 and 56 visits counted on flowers respectively in 2016 and 2017, $26(59.09 \%)$ and $30(53.57 \%)$ were for nectar collection, $11(25.00 \%)$ and $17(30.36 \%)$ for pollen collection, respectively in 2016 and 2017 (Table 2). For the total of 100 visits recorded during the two seasons, the number of visits allocated to nectar harvest was $56(56.00 \%)$ and that for pollen collection was $28(28.00 \%)$.

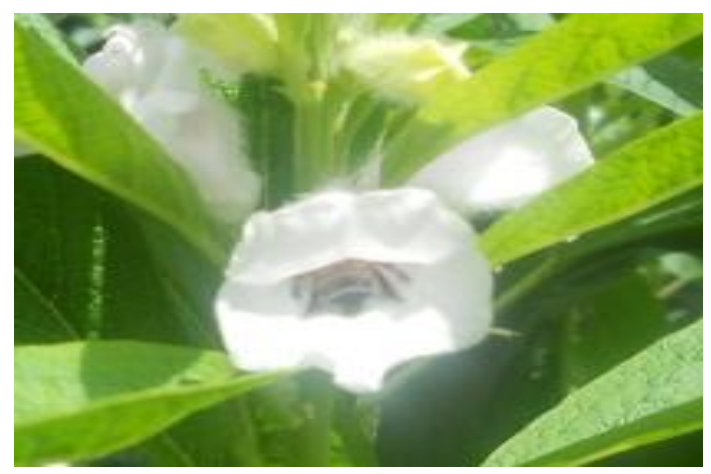

Figure2. Apis mellifera collecting nectar in a flower of Sesamum indicum

Table2. Products harvested by Apis mellifera on flowers of Sesamum indicum in 2016 and 2017 at Bilone

\begin{tabular}{|l|l|l|l|l|l|l|l|}
\hline year & Number of & \multicolumn{2}{l|}{ Visits for nectar harvest } & \multicolumn{2}{l|}{ Visits for pollen harvest } & \multicolumn{2}{l|}{ Visits for nectar and pollen harvest } \\
\cline { 3 - 8 } & visits studied & Number & $\%$ & Number & $\%$ & Number & $\%$ \\
\hline 2016 & 44 & 26 & 59.09 & 11 & 25.00 & 7 & 15.91 \\
\hline 2017 & 56 & 30 & 53.57 & 17 & 30.36 & 9 & 16.07 \\
\hline
\end{tabular}

\subsubsection{Abundance of Apis mellifera workers}

In 2016, the highest mean number of A. mellifera workers simultaneously in activity active was one per flower $(n=35 ; s=0)$ and 207 per 1000 flowers $(n=27 ; s=102)$. In 2017, the corresponding figures were 1 per flower $(n=35 ; s=0)$ and 258 per 1000 flowers $(n=30 ; s=98)$. The difference between the mean number of bees per 1000 flowers in 2016 and 2017 was significant $(t=-1.89 ; d f=55 ; P<0.05)$.

\subsubsection{Duration of visits per flower}

The mean duration of $A$. mellifera visit on flower of $S$. indicum depended on the substance collected (table 3). In 2016, the mean duration of a visit was $2.37 \mathrm{sec}(n=11 ; s=0.12)$ for pollen collection against $3.97 \mathrm{sec}(n=26 ; s=1.88)$ for nectar harvest. In 2017, the corresponding results were $2.17 \mathrm{sec}(n=17 ; s=0.47)$ for pollen harvest and $4.26 \mathrm{sec}(n=30 ; s=0.58)$ for nectar collection. The differences between the duration of a visit to harvest nectar $(t=-0.78 ; d f=54, P>0.05)$ and that for pollen $(t=-1.33 ; d f=26 ; P>0.05)$ collection are not significant in 2016 and 2017. The difference between the 
Pollination Efficiency of Apis mellifera L. (Hymenoptera: Apidae) on Flowers of Sesamum indicum L. (Pedaliaceae) at Bilone (Obala, Cameroon)

mean duration of the visit for pollen harvest and that for nectar collection was significant $(t=3.95$; $d f=80 ; P<0.001)$.

Table3. Duration of Apis mellifera visits on flowers of Sesamum indicum in 2016 and 2017 at Bilone

\begin{tabular}{|l|l|l|l|l|l|l|}
\hline \multirow{2}{*}{ year } & \multicolumn{4}{|l|}{ Visit for nectar harvest } & \multicolumn{4}{l|}{ Visit for pollen harvest } \\
\cline { 2 - 7 } & $n$ & $m$ & $s$ & $n$ & $m$ & 年 \\
\hline 2016 & 26 & 3.97 & 1.88 & 11 & 2.37 & 0.12 \\
\hline 2017 & 30 & 4.26 & 0.58 & 17 & 2.17 & 0.47 \\
\hline
\end{tabular}

\subsection{Foraging speed of Apis mellifera on the flowers of Sesamum indicum}

On the flowers of $S$. indicum, A. mellifera visited 5 to 12 flowers/min in 2016 and 5 to 15 flowers/min in 2017. The mean foraging speed was 9 flowers/min $(n=30 ; s=3.12)$ in 2016 and 11 flowers/min $(n=30 ; s=2.83)$ in 2017. The difference between these two means is highly significant $(t=-10.49 ; d f=58 ; P<0.001)$.

\subsubsection{Daily rhythm of visits}

Apis mellifera workers were active on the flowers of $S$. indicum from 9 am to $16 \mathrm{pm}$, with a peak of visits between 9 am and 10 am in 2016 and in 2017 (Figure 3). Climatic conditions have influenced the activity of $A$. mellifera workers on $S$. indicum flowers in field conditions. The correlation was positive and higher significant between the number of A. mellifera visits on $S$. indicum flowers and temperature in $2016(r=0.98 ; d f=3 ; P<0.05)$ and not significant between these two parameters in 2017 $(r=-0.60 ; d f=3 ; P>0.05)$. The correlation between the number of visits and the relative humidity of the air was not significant in $2016(r=0.10 ; d f=3 ; P>0.05)$ as well as in $2017(r=-0.40 ; d f=3$; $P>0.05$ ) (figure 4).

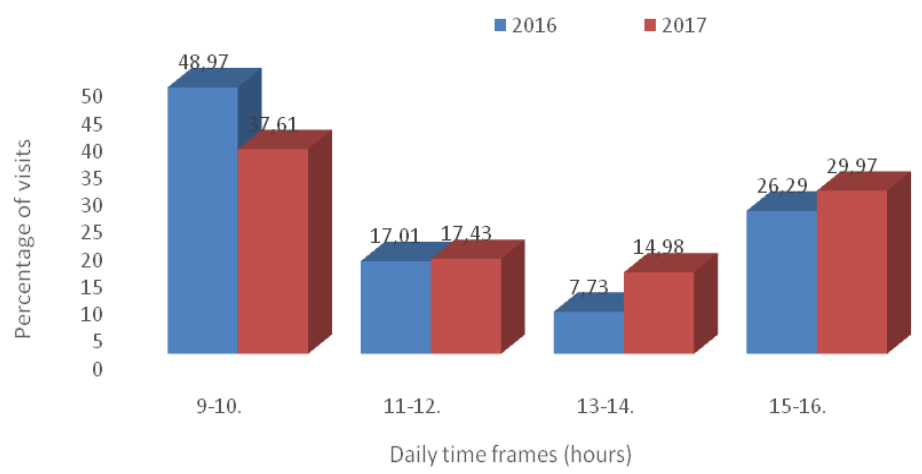

Figure3. Distribution of visits of Apis mellifera on the flowers of Sesamum indicum according to daily time in 2016 and 2017

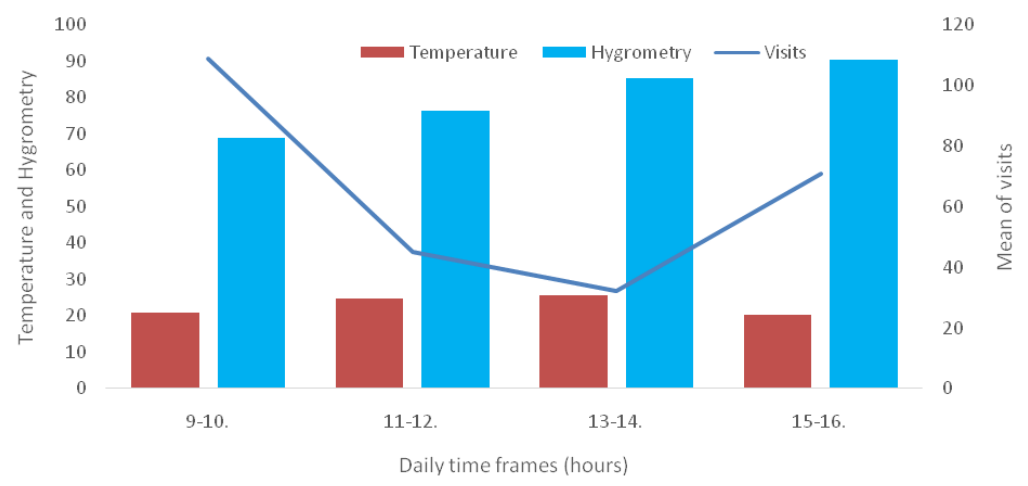

Figure4. Mean daily temperature and humidity and mean number of visits of Apis mellifera on Sesamum indicum flowers in 2016 and 2017

\subsubsection{Apicultural value of Sesamum Indicum}

During the mild rainy season in Bilone, we noted a well elaborated activity of A. mellifera workers on 
Pollination Efficiency of Apis mellifera L. (Hymenoptera: Apidae) on Flowers of Sesamum indicum L. (Pedaliaceae) at Bilone (Obala, Cameroon)

S. indicum flowers. In particular, there was a very good nectar harvest, a good pollen collection and workers faithfulness to its flowers. These data allow to place $S$. indicum highly nectariferous and polliniferous bee plants.

\subsection{Impact of flower-feeding insects in pollination and yields of Sesamum indicum}

During pollen and nectar harvest, fowering insects of $S$. indicum were in regular contact with the anthers and stigma. Thus these insects increased the pollination possibilities of this plant species. Table 4 presents the results on the fruiting rate, the number of seeds per pod and the percentage of normal seeds in different treatments. From this table, we documented the following:

a. The comparison of the fruiting rate showed that the difference was significant between treatment 1 (opened flowers) and treatment 2 (bagged flowers) in the first year $\left(\chi^{2}=2.71 ; d f=1 ; p<0.1\right)$ and not significant between these two treatments in the second year $\left.\chi^{2}=1.17 ; d f=1 ; p>0.05\right)$. Consequently, in 2016 and 2017, the fruiting rate of opened flowers was higher than that of bagged flowers $\left(\chi^{2}=4.99 ; d f=1 ; p<0.05\right)$.

b. The comparison of the mean number of seeds per pod showed that the difference were highly significant between treatments 1 and $2(t=10.60 ; d f=59 ; p<0.001)$ in 2016 and in $2017(t=18.29$; $d f=59 ; p<0.001)$. Consequently, in 2016 and 2017, a mean number of seeds per pod of the unprotected flowers were higher than that of protected flowers.

c. The comparison of the percentage of normal seeds showed that the difference were highly significant between opened flowers (treatment 1$)$ and bagged flowers (treatment 2 ) in the first year $(\chi 2=6.17 ; \mathrm{df}=1 ; \mathrm{p}<0.001)$ as well as in the second year $(\chi 2=26.62 ; \mathrm{df}=1 ; \mathrm{p}<0.001)$. Thus, in 2016 and 2017 the percentage of normal seeds in opened flowers was higher than that of protected flowers in 2016 and in 2017.

The numeric contribution of pollinating insects to the fruiting rate, the mean number of seeds per pod and the percentage of normal seeds were respectively $26.70 \%, 16.07 \%$ and $3.31 \%$ in 2016 . The corresponding figures were $0 \%, 13.33 \%$ and $6.74 \%$ in 2017 . For the two cumulate years, the numeric contributions were $13.35 \%, 14.70 \%$ and $5.02 \%$ for the fruiting rate, the mean number of seeds per pods and the percentage of normal seeds respectively. The impact of pollinating insects on pod and seed yields was positive and significant.

\subsection{Pollination efficiency of Apis mellifera on Sesamum indicum}

From Table 4, it appears that:

a. The comparison of the fruiting rate showed that the difference were not significant between treatment 3 (flowers protected and visited exclusively by A. mellifera) and treatment 2 (bagged flowers $)$ in $2016\left(\chi^{2}=0.23 ; d f=1 ; p>0.05\right)$ as well as in $2017\left(\chi^{2}=0.48 ; d f=1 ; p>0.05\right)$.

b. The comparison of the mean number of seeds per pod showed that the difference were highly significant between treatments 3 and $2(t=8.22 ; d f=43 ; p<0.001)$ in the first year and in the second year $(t=6.20 ; d f=47 ; p<0.001)$. Consequently, in 2016 and 2017 , the pods produce by flowers bagged and visited exclusively by $A$. mellifera produced more seeds than those of protected flowers.

c. The comparison of the percentage of normal seeds showed that the difference were highly significant between treatment 3 and treatment 2 in $2016\left(\chi^{2}=51.09 ; d f=1 ; p<0.001\right)$ and in 2017 $\left(\chi^{2}=28.07 ; d f=1 ; p<0.001\right)$ respectively. For the two years, the pods produce by flowers bagged and visited exclusively by $A$. mellifera have more normal seeds than those of protected flowers.

The numeric contribution of A. mellifera on the mean of number of seed per pod and the percentage of normal seeds were respectively $17.54 \%$ and $9.53 \%$ in 2016 . The corresponding results were $8.77 \%$ and $7.70 \%$ in 2017. For the two years, the numeric contributions of A. mellifera were $13.15 \%$ and $8.61 \%$ for the mean number of seeds per pods and the percentage of normal seeds respectively. The impact of $A$. mellifera on pods and seeds yields was positive and significant. 
Pollination Efficiency of Apis mellifera L. (Hymenoptera: Apidae) on Flowers of Sesamum indicum L. (Pedaliaceae) at Bilone (Obala, Cameroon)

Table4. Fruiting rate, number of seed per pod and percentage of normal seeds according to different treatments of Sesamum indicum in 2016 and 2017 at Bilone

\begin{tabular}{|c|c|c|c|c|c|c|c|c|c|}
\hline \multirow[t]{2}{*}{ Treatment } & \multirow[t]{2}{*}{ year } & \multirow[t]{2}{*}{ Flowers } & \multirow[t]{2}{*}{ pod } & \multirow{2}{*}{$\begin{array}{l}\text { Fruiting } \\
\text { rate }\end{array}$} & \multicolumn{2}{|c|}{ Seeds / pod } & \multirow{2}{*}{$\begin{array}{l}\text { Total } \\
\text { Seeds }\end{array}$} & \multirow{2}{*}{$\begin{array}{l}\text { Normal } \\
\text { Seeds }\end{array}$} & \multirow{2}{*}{$\begin{array}{l}\text { \% Normal } \\
\text { seeds }\end{array}$} \\
\hline & & & & & $m$ & $s$ & & & \\
\hline $\begin{array}{l}\text { Unlimited } \\
\text { visits }\end{array}$ & \multirow[t]{3}{*}{2016} & 45 & 35 & 77.77 & 56 & 14 & 2205 & 1938 & 87.89 \\
\hline $\begin{array}{l}\text { Bagged } \\
\text { flowers }\end{array}$ & & 45 & 26 & 57.00 & 47 & 10 & 1352 & 1149 & 84.98 \\
\hline $\begin{array}{l}\text { Apis } \\
\text { mellifera }\end{array}$ & & 30 & 19 & 63.33 & 55 & 11 & 1140 & 1071 & 93.94 \\
\hline $\begin{array}{l}\text { Unlimited } \\
\text { visits }\end{array}$ & \multirow[t]{3}{*}{2017} & 45 & 33 & 73.33 & 60 & 9 & 2112 & 1880 & 89.01 \\
\hline $\begin{array}{l}\text { Bagged } \\
\text { flowers }\end{array}$ & & 45 & 28 & 62.00 & 52 & 7 & 1548 & 1285 & 83.01 \\
\hline $\begin{array}{l}\text { Apis } \\
\text { mellifera }\end{array}$ & & 30 & 21 & 70.00 & 57 & 12 & 1323 & 1190 & 89.94 \\
\hline
\end{tabular}

\section{DISCUSSION}

Apis mellifera was the main floral visitor of $S$. indicum during the observation period. This bee has been reported as the main floral visitor of this plant in Egypt [18] and in Northwest Region of Cameroon [12]. Apis mellifera was also shown to be the most abundant floral visitors of other Fabaceae members such as Glycine max in Douala [19], Phaseolus vulgaris in Ngaoundere [20] and in Maroua [21]. The peak of the activity of A. mellifera on S. indicum flowers was located between 9 and $10 \mathrm{am}$, which correlated with the highest availability period of nectar on $S$. indicum flowers. The significant difference between the mean duration of the visit for pollen harvest and that for nectar collection could be attributed to the availability of floral products or the variation in the diversity of flowering insects from one year to another. During each flowering periods of S. indicum, $A$. mellifera harvested nectar and pollen. This could be attributed to the needs of colonies during the corresponding period. This research, indicates that A. mellifera can provide benefits to pollination management of $S$. indicum. During the collection of nectar and pollen on each flower, A. mellifera foragers regularly come into contact with the stigma. They were also able to carry pollen with their hairs, legs and mouth accessories from a flower of one plant to stigma of another flower of the same plant (geitonogamy), to the same flower (autogamy) or to that of another plant (xenogamy) [2]. The significant contribution of A. mellifera in pods and seed yield of $S$. indicum is in agreement with the similar findings in Egypt [18, 22] and in Northwest Region of Cameroon [12] on the same pedaliaceae. This plant species produces fewer seeds per pod in the absence of efficient pollinators [23]. The contribution of $A$. mellifera to $S$. indicum production through its pollination efficiency was significantly higher than that of all insects on the exposed flowers. The weight of $A$. mellifera played a positive role during nectar and pollen collection. Apis mellifera shook flowers and could facilitate the liberation of pollen by anthers for the optimal occupation of the stigma. This phenomenon was also reported by Tchuenguem and Dounia [24] on Glycine max in Maroua (Cameroon). The higher production of seeds per pod and that of normal seeds in the treatment with flowers visited exclusively by A. mellifera workers compared to that of the treatment with protected flowers showed that A. mellifera visit was effective in increasing pollination. Our results confirmed those of Atibita [23] who revealed that $S$. indicum flowers set little pods in the absence of insect pollinators.

\section{CONCLUSION}

This study reveals that the variety of $S$. indicum studied is a highly nectariferous and polliniferous bee plant that obtained benefits from the pollination by insects among which $A$. mellifera is the most important. The comparison of pod and seed sets of protected flowers to that of flowers visited exclusively by A. mellifera underscores the value of this bee in increasing pod and seed productions as well as seed quality. In the Center Region of Cameroon, the installation of $A$. mellifera hive close to $S$. indicum fields is recommended for the increase of the seed yields of this valuable crop.

\section{REFERENCES}

[1] McGregor S. E., Insect pollination of cultivated crop plants. Agricultural Research Service. United States Department of Agriculture, Agriculture Handbook, Washington, no. 496, Pp. 411 (1976). 
Pollination Efficiency of Apis mellifera L. (Hymenoptera: Apidae) on Flowers of Sesamum indicum L. (Pedaliaceae) at Bilone (Obala, Cameroon)

[2] Philippe J. M., La pollinisation par les abeilles: pose des colonies dans la culture en floraison en vue d'accroître les rendements des productions végétales. EDISUD la calade Aix-en-Provence. Pp. 179 (1991).

[3] Tchuenguem F. F.-N., Foraging and pollination activity of Apis mellifera adansonii Latreille (Hymenoptera: Apidae, Apinae) on flowers of three plants at Ngaoundéré (Cameroon): Callistemon rigidus (Myrtaceae), Sygygium guineense var. macrocarpum (Myrtaceae) and Voacanga Africana (Apocynaceae). State doctorate, University of Yaounde I. Pp. 103 (2005).

[4] Desai B. B., 2004. Seeds handbook; biology, production, processing and storage. Science, $2^{\text {nd }}$ edition, New York. Pp. 787 (2004).

[5] Langham D. R., Phenology of sesame. Reprinted from: Issues in new crops and new uses. J. Janick and A. Whipkey (eds.). ASHS Press, Alexandria, Pp. 144-182 (2007).

[6] Ashri A., Sesame breeding. In: Plant Breeding Reviews. Edited by: Janick J. Oxford: John Wiley. Vol. 16. (2010).

[7] MINADER, Annuaire des Statistiques du Secteur Agricole, Campagnes 2009 \& 2010. Direction des Enquêtes et Statistiques AGRI - STAT CAMEROUN n 17, Pp. 123 (2012).

[8] Mkamilo G.S. and Bedigian D., Sesamum indicum L. In: van der Vossen, H.A.M. \& Mkamilo, G.S. (Editors). PROTA 14: Vegetable oils/Oléagineux. [CD-Rom]. PROTA, Wageningen, Netherlands. (2007).

[9] Kandangath R A., Ajay P., Farhath K. and Amarinder S.B., Nutritional, Medicinal and Industrial Uses of Sesame (Sesamum indicum L.) Seeds - An Overview. Agriculturae Conspectus Scientificus, 75 (4): 159-168 (2010).

[10] Viraktmath S.A., Patil B., Murasing S. and Guruprasad G.S., Relative abundance of pollinator fauna of cross-pollinated oilseed crops at Dharwad in Karnataka (India). Indian Bee J., 63 (3-4): 64-67 (2001).

[11] Kamel S. M., Blal A. H., Mahfouz H. M. and Said M., The most common insect pollinator species on sesame crop (Sesamum indicum L.) in Ismailia Governorate, Egypt. Arthropods, 2 (2): 66-74 (2013).

[12] Atibita O. E. N., Tchuenguem F. F. - N and Djieto-Lordon C., Diversité de l'entomofaune floricole de Sesamum indicum (L.) 1753 (Pedaliaceae) et son impact sur les rendements fruitiers et grainiers à Bambui (Nord-Ouest, Cameroun). Int. J. Biol. Chem. Sci.10 (1): 106-119 (2016).

[13] Roubik D. W., Pollination system stability in Tropical America. Conserv. Biol., 14 (5): 1235-1236 (2000).

[14] Letouzey R., Notice de la carte phytogéographique du Cameroun au 1/500000. Inst. Carte Intern. Végétation, Toulouse et Inst. Rech. Agron., Yaoundé (1985).

[15] Suchet J. P., Les climats du Cameroun. Thèse de Doctorat d'Etat, Université de Bordeaux-France, Pp.7971097 (1988).

[16] Tchuenguem F. F. - N., Messi J., Brückner D., Bouba B., Mbofung G. and Hentchoya Hemo J., Foraging and pollination behaviour of the African honey bee (Apis mellifera adansonii) on Callistemon rigidus flowers at Ngaoundéré (Cameroon). Journal of the Cameroon Academy of Sciences, 4: 133-140 (2004).

[17] Demarly Y., Genetic and amelioration of plants. Masson, Paris. Pp. 577 (1977).

[18] Mahfouz H.M., Kamel S.M., Belal A.H. and Said M., Pollinators visiting sesame (Sesamum indicum L.) seed crop with reference to foraging activity of some bee species. Cercetâri Agronomice în Moldova, XLV (2): 150-161 (2012).

[19] Taimanga and Tchuenguem F. F.-N., Diversité des insectes floricoles et son impact sur les rendements fruitiers et grainiers de Glycine max (Fabaceae) à Yassa (Douala, Cameroun), Int. J. Biol. Chem. Sci. 12(1): 141-156 (2018).

[20] Kingha B.M.T., Tchuenguem F.F.-N., Ngakou A. and Brückner D., Foraging and pollination activities of Xylocopa olivacea (Hymenoptera, Apidae) on Phaseolus vulgaris (Fabaceae) flowers at Dang (Ngaoundere-Cameroon). Journal of Agricultural Extension and Rural Development, 4(6): 330-339 (2012).

[21] Douka C. and Tchuenguem F. F.-N., Foraging and pollination Behavior of Apis mellifera adansonii Latreille (Hymenoptera: Apidae) on flowers of Phaseolus vulgaris L. (Fabaceae) at Maroua, Cameroon. International Research Journal of Plant Science, 4 (2): 45-54 (2013). 
Pollination Efficiency of Apis mellifera L. (Hymenoptera: Apidae) on Flowers of Sesamum indicum L. (Pedaliaceae) at Bilone (Obala, Cameroon)

[22] Rakesh K. and Lenin J.K., Insect pollinators and effects of cross pollination on yield attributes of sesame (Sesamum indicum L.), Indian Bee J., 62 (1-2): 75-80 (2000).

[23] Otiobo A. E. N., Activités de butinage et de pollinisation de Amegilla sp. et Apis mellifera adansonii (Hymenoptera: Apidae) sur les fleurs de Physalis micrantha Link (Solanaceae) et Sesamum indicum Linnaeus (Pedaliaceae) à Bambui (Mezam, Cameroun). Thèse de Doctorat/Ph.D., Faculté des Sciences, Université de Yaoundé I, Pp.190 (2017).

[24] Tchuenguem F. F. - N. and Dounia, Foraging and pollination behavior of Apis mellifera adansonii Latreille (Hymenoptera: Apidae) on Glycine max L. (Fabaceae) flowers at Maroua. Journal of Research in Biology, 4 (1): 1209-1219 (2014).

Citation: Pharaon Mbianda Auguste et al., "Pollination Efficiency of Apis Mellifera L. (Hymenoptera: Apidae) on Flowers of Sesamum Indicum L. (Pedaliaceae) at Bilone (Obala, Cameroon)", International Journal of Research Studies in Agricultural Sciences, vol. 4, no. 3, p. 1-9, 2018. http://dx.doi.org/10.20431/2454-6224.0403003

Copyright: (C) 2018 Autors. This is an open-access article distributed under the terms of the Creative Commons Attribution License, which permits unrestricted use, distribution, and reproduction in any medium, provided the original author and source are credited. 